\title{
SARINGAN CANGKANG TELUR BEBEK EFEKTIF MEMPERBAIKI KUALITAS PH DAN BESI AIR SUMUR BOR
}

\section{Rahmatullah Jati Pradopo, Sulaiman Hamzani, Syarifudin A.}

Poltekkes Kemenkes Banjarmasin Jurusan Kesehatan Lingkungan

Jl. H. Mistar Cokrokusumo No.1A Banjarbaru Kalimantan Selatan 70714

e-mail: rahmatpradopo59@gmail.com

\begin{abstract}
Duck Eggshell Water Filter Effectively Improves pH And Iron Quality Of Drilling Well Water. Water well drill that is in the Pondok Pesantren Hidayatullah Banjarbaru seen physically yellowish and smelly. Preliminary test result obtained pH 4.9 and $\mathrm{Fe} 2.5 \mathrm{mg} / \mathrm{L}$. Based on the quality of clean water standards have not fulfilled the requirements of $1.0 \mathrm{mg} / \mathrm{L}$ and $\mathrm{pH}$ 6.5-8.5. It needs to be done research test of duck egg filter making in improving the quality of $\mathrm{pH}$ and Fe water well drill. The goal of this research is to know the effectiveness of duck egg filter in improving the quality of $p H$ and Fe water wells drill. Types of research are experiments with pretest-posttest with control group. The population in the research is the whole water well drill in the Pondok Pesantren Hidayatullah Banjarbaru. A research sample is a water well drill that is partially taken for trial. Analysis of the influence thickness of the sieve using Anova asymp Test $<\propto(0.000<0.05)$ means there is a difference between the filter thickness of duck egg, $0 \mathrm{~cm}, 20 \mathrm{~cm}, 40 \mathrm{~cm}, 60 \mathrm{~cm}$. Then done test Posh Hoc Tests can be concluded that there is a meaningful difference between the thickness of the filter of duck egg shells $0 \mathrm{~cm}, 20$ $\mathrm{cm}, 40 \mathrm{~cm}, 60$ Based on the research results of the sieve $40 \mathrm{~cm}$ with a weight of $291 \mathrm{gram}$ is an effective sieve in lowering the water level of the well drill.
\end{abstract}

Keywords: Filter; egg shells; iron Content; drilled well water

Abstrak: Saringan Cangkang Telur Bebek Efektif Memperbaiki Kualitas pH Dan Kadar Besi Air Sumur Bor. Air sumur bor yang berada di Pondok Pesantren Hidayatullah Banjarbaru dilihat secara fisik berwarna kekuningan dan berbau. Hasil pemeriksaan uji pendahuluan didapatkan hasil pemeriksaan $\mathrm{pH}$ 4,9 dan $\mathrm{Fe}$ 2,5 $\mathrm{mg} / \mathrm{L}$. Berdasarkan baku mutu air bersih belum memenuhi persyaratan yaitu 1,0 $\mathrm{mg} / \mathrm{L}$ dan $\mathrm{pH}$ 6,5-8,5. Perlu dilakukan uji penelitian pembuatan saringan cangkang telur bebek dalam memperbaiki kualitas $\mathrm{pH}$ dan $\mathrm{Fe}$ air sumur bor. Tujuan penelitian ini adalah mengetahui Efektivitas saringan cangkang telur bebek dalam memperbaiki kualitas $\mathrm{pH}$ dan Fe air sumur bor. Jenis penelitian yaitu eksperimen dengan pretest-posttest with control group. Populasi pada penelitian yaitu seluruh air sumur bor di Pondok Pesantren Hidayatullah Banjarbaru. Sampel penelitian yaitu air sumur bor yang diambil sebagian untuk uji coba. Analisis pengaruh ketebalan saringan menggunakan uji Anova asymp $<\propto(0.000<0.05)$ artinya ada perbedaan antara ketebalan saringan cangkang telur bebek $0 \mathrm{~cm}, 20 \mathrm{~cm}, 40$ $\mathrm{cm}, 60 \mathrm{~cm}$. Maka dilakukan Uji Posh Hoc Tests dapat disimpulkan bahwa ada perbedaan yang bermakna antara ketebalan saringan cangkang telur bebek $0 \mathrm{~cm}, 20 \mathrm{~cm}, 40 \mathrm{~cm}, 60$ $\mathrm{cm}$ terhadap penurunan kadar besi. Berdasarkan hasil penelitian saringan $40 \mathrm{~cm}$ dengan berat 291 gram adalah saringan yang efektif dalam menurunkan kadar besi air sumur bor.

Kata Kunci: Saringan; cangkang telur; kadar besi; air sumur bor

\section{PENDAHULUAN}

Salah satu alternatif sumber air untuk keperluan sehari-hari yaitu sumur bor, Tingginya kadar besi yang terdapat pada sumur bor tersebut telah menjadi permasalahan yang belum teratasi jadi sebelum digunakan harus dilakukan pengolahan terlebih dahulu. Limbah rumah tangga yang belum dimanfaatkan secara maksimal yaitu salah satunya cangkang telur. Cangkang telur mengandung senyawa kalsium karbonat (CaCO3), 
Cangkang telur juga memiliki banyak pori-pori yang berukuran nano sehingga diperkirakan dapat digunakan sebagai adsorben yang lebih efektif[1].

Salah satu upaya yang dapat dilakukan untuk menurunkan kadar besi dalam air adalah dengan cara filtrasi. Filtrasi adalah proses penyaringan partikel secara fisik, kimia, dan biologi untuk memisahkan atau menyaring partikel yang tidak terendapkan di sedimentasi melalui media berpori.

Pada uji coba penelitian pengolahan air sumur bor dengan metode saringan cangkang telur dengan menggunakan media cangkang telur bebek dengan berbagai variasi ketebalan yang berbeda. Pemilihan metode ini didasarkan atas pengunaan biaya yang di keluarkan kecil, serta tidak sulit pada saat proses pembuatannya. Berdasarkan hasil survey di lokasi pengambilan sampel yaitu di Pondok Pesantren Hidayatullah Kecamatan Landasan Ulin Banjarbaru, air sumur berwarna kekuningan, dan berbau dilihat secara fisik. Hasil pemeriksaan uji pendahuluan didapatkan hasil pemeriksaan $\mathrm{pH}$ 4,9 dan Fe 2,5 mg/L[1]. Berdasarkan standar belum memenuhi persyaratan menurut Permenkes RI No. 32 Tahun 2017 yaitu 1,0 mg/L dan pH 6,5-8,5[2]. Dari permasalahan di atas, peneliti ingin melakukan penelitian tentang pengolahan air dengan metode saringan cangkang telur bebek dengan berbagai variasi ketebalan yang berbeda yaitu $(0 \mathrm{~cm}, 20 \mathrm{~cm}$, $40 \mathrm{~cm}$ dan $60 \mathrm{~cm}$ ) untuk menurunkan kadar besi pada air.

\section{BAHAN DAN CARA PENELITIAN}

Penelitian yang dilakukan yaitu eksperimen tentang pengolahan air sumur bor dengan variasi saringan dan ketebalan cangkang telur yang berbeda, Uji dilakukan untuk pemeriksaan kadar Fe. Sebelum proses perlakuan pada sampel air sumur bor, terlebih dahulu dilakukan pemeriksaan awal kadar $\mathrm{pH}$. Selanjutnya dilakukan perlakuan pada sumber air sumur bor yang sama dengan filtrasi saringan cangkang telur bebek dengan variasi ketebalan yang berbeda lalu dilakukan lagi pengukuran kadar $\mathrm{pH}$ setelah melewati alat saringan[1]. Sedangkan untuk pengukuran besi (Fe) dilakukan di Labolatorium BBTKLPP Banjarbaru sampel yang diperiksa yaitu sampel sebelum perlakuan dan sesudah perlakuan. Setelah selesai pengukuran pada kelompok eksperimen, lalu hasilnya dibandingkan untuk mengetahui adanya perbedaan dengan kelompok eksperimen berasal dari pengaruh dilakukannya intervensi. Hasil data ditampilkan dalam bentuk tabel serta grafik. Hasil dibandingkan dengan Persyaratan Kesehatan Air Untuk Keperluan Higiene Sanitasi menurut Permenkes RI No. 32 Tahun 2017[2].

\section{HASIL PENELITIAN DAN PEMBAHASAN}

Hasil pada uji pendahuluan air sumur bor diketahui kadar Fe sebesar 2,5 $\mathrm{mg} / \mathrm{L}$ dan $\mathrm{pH} 4,9$. Pada air sumur bor kemudian dilakukan perlakuan kemudian hasil dari sampel besi dan $\mathrm{pH}$ dapat dilihat pada tabel berikut:

Tabel 1. Hasil Pengukuran Suhu (oC) Sebelum dan Sesudah Dilakukan Perlakuan

\begin{tabular}{|c|c|c|c|c|c|}
\hline \multirow[t]{2}{*}{ No } & \multicolumn{2}{|c|}{ Pengulangan } & \multicolumn{2}{|c|}{ Suhu Air ( $\left({ }^{\circ} \mathrm{C}\right)$} & \multirow{3}{*}{ Saringan $60 \mathrm{~cm}$} \\
\hline & & $0 \mathrm{~cm}$ & Saringan $20 \mathrm{~cm}$ & Saringan $40 \mathrm{~cm}$ & \\
\hline 1 & P1 & 26,6 & 27 & 27 & \\
\hline 2 & P2 & 26,7 & 26,8 & 27 & 26,9 \\
\hline 3 & P3 & 26,6 & 26,8 & 26,9 & 26,6 \\
\hline & Rata-rata & 26,6 & 26,8 & 26,9 & 26,7 \\
\hline & Sebelum & 26,6 & 27 & 27 & 26,8 \\
\hline
\end{tabular}

Dari hasil pengukuran suhu pada sampel air sumur bor sebelum perlakuan berkisar 26,6으 $27 \circ \mathrm{C}$ dan sesudah perlakuan dengan menggunakan saringan cangkang telur bebek menunjukan bahwa dari 3 kali pengulangan dengan 4 saringan 
yang berbeda yaitu saringan $0 \mathrm{~cm}, 20 \mathrm{~cm}$, $40 \mathrm{~cm}, 60 \mathrm{~cm}$ kisaran suhu pada air sumur bor antara $26,6 \circ \mathrm{C}-27 \circ \mathrm{C}$. Adapun rata-rata suhu pada saringan $0 \mathrm{~cm}$ yaitu sekitar $26,6 \circ \mathrm{C}$, Saringan $20 \mathrm{~cm}$ sekitar $26,8 \circ \mathrm{C}$,
Sedangkan saringan $40 \mathrm{~cm}$ sekitar $26,9 \circ \mathrm{C}$, dan Saringan $60 \mathrm{~cm}$ sekitar $26,7 \circ \mathrm{C}$. Hasil dari sampel $\mathrm{pH}$ dapat dilihat pada tabel 2 berikut:

Tabel 2. Hasil Pengukuran pH Sebelum dan Sesudah Dilakukan Perlakuan

\begin{tabular}{rrrccc}
\hline No & Pengulangan & \multicolumn{5}{c}{ pH Air } \\
\hline \multicolumn{7}{r}{} & & Saringan 0 cm & Saringan 20 cm & Saringan $40 \mathrm{~cm}$ & Saringan 60 cm \\
\hline & P1 & 6,7 & 7,4 & 8,4 & 8,3 \\
& P2 & 6,7 & 7,6 & 8,3 & 8,2 \\
3 & P3 & 6,6 & 7,7 & 8,4 & 8,2 \\
\hline \multicolumn{7}{r}{ Rata-rata } & 6,6 & 7,5 & 8,3 & 8,2 \\
\hline & Sebelum & 4,9 & 4,9 & 4,9 & 4,9 \\
\hline
\end{tabular}

Dari hasil pengukuran pH sampel air sumur bor sebelum dilakukan perlakuan berkisar 4,9 dan sesudah dilakukan perlakuan dengan menggunakan saringan cangkang telur bebek menunjukan bahwa dari 3 kali pengulangan dengan 4 saringan yang berbeda yaitu saringan $0 \mathrm{~cm}, 20 \mathrm{~cm}, 40 \mathrm{~cm}, 60 \mathrm{~cm}$ kisaran pH pada air sumur bor antara 6,68,4 . Adapun rat-rata $\mathrm{pH}$ pada saringan 0 $\mathrm{cm}$ yaitu sekitar 6,6. Saringan $20 \mathrm{~cm}$ sekitar 7,5. Sedangkan saringan $40 \mathrm{~cm}$ sekitar 8,3 dan Saringan $60 \mathrm{~cm}$ sekitar 8,2. Hasil dari sampel kadar besi dapat dilihat pada tabel 3 berikut :

Tabel 3. Hasil Pengukuran Kadar Besi Menggunakan Saringan 0cm

\begin{tabular}{cccccc}
\hline No & Pengulangan & \multicolumn{2}{c}{ Kadar Fe (mg/L) } & Penurunan (mg/L) & Keefektifan \\
\hline & & Sebelum & Sesudah & & $(\%)$ \\
\hline 1 & P1 & \multirow{2}{*}{2,57} & 3,26 & $-0,69$ & $-26,85 \%$ \\
& P2 & & 2,16 & 0,41 & $15,95 \%$ \\
& P3 & & 1,95 & 0,62 & $24,12 \%$ \\
\hline & Rata-rata & 2,45 & 0,57 & $22,30 \%$ \\
\hline
\end{tabular}

Dari hasil pengukuran kadar besi yang mengalami penurunan pada sampel air sumur bor sebelum dilakukan perlakuan sebesar 2,57 $\mathrm{mg} / \mathrm{L}$ dan sesudah dilakukan perlakuan dengan menggunakan saringan cangkang telur bebek menunjukan bahwa dari 3 kali pengulangan kadar besi pada air mengalami penurunan dari sebelum perlakuan dengan sesudah perlakuan. Hasil pengukuran terhadap penurunan kadar besi pada air sumur bor setelah dilakukan perlakuan berkisar antara 0,41 $\mathrm{mg} / \mathrm{L} \quad(15,95 \%)$ sampai $0,62 \mathrm{mg} / \mathrm{L}$ (24,12\%). Adapun hasil rata-rata penurunan kadar besi setelah dilakukan perlakuan sekitar 0,57 mg/L (22,30\%).

Tabel 4. Hasil Pengukuran Kadar Besi Menggunakan Saringan $20 \mathrm{~cm}$

\begin{tabular}{|c|c|c|c|c|c|}
\hline \multirow[t]{2}{*}{ No } & \multirow[t]{2}{*}{ Pengulangan } & \multicolumn{2}{|c|}{ Kadar Fe (mg/L) } & \multirow[t]{2}{*}{ Penurunan (mg/L) } & \multirow{2}{*}{$\begin{array}{c}\text { Keefektifan } \\
(\%) \\
\end{array}$} \\
\hline & & Sebelum & Sesudah & & \\
\hline 1 & P1 & & 1,25 & 1,32 & $51,36 \%$ \\
\hline 2 & P2 & 2,57 & 1,43 & 1,14 & $44,36 \%$ \\
\hline 3 & P3 & & 0,76 & 1,81 & $70,43 \%$ \\
\hline & Rata-rata & & 1,14 & 1,42 & $55,38 \%$ \\
\hline
\end{tabular}


Dari hasil pengukuran terhadap penurunan kadar besi pada sampel air sumur bor sebelum dilakukan perlakuan berkisar 2,57 $\mathrm{mg} / \mathrm{L}$ dan sesudah dilakukan perlakuan dengan menggunakan saringan cangkang telur bebek menunjukan bahwa dari 3 kali pengulangan kadar besi pada air mengalami penurunan dari sebelum perlakuan dengan sesudah perlakuan. Hasil pengukuran terhadap Penurunan kadar besi pada air sumur bor setelah dilakukan perlakuan berkisar antara $1,14 \mathrm{mg} / \mathrm{L}$ (44,36\%) sampai $1,81 \mathrm{mg} / \mathrm{L}$ (70,43\%). Adapun hasil rata-rata penurunan kadar besi pada air setelah dilakukan perlakuan sekitar 1,42 mg/L (55,38\%).

Tabel 5. Hasil Pengukuran Kadar Besi Menggunakan Saringan 40cm

\begin{tabular}{|c|c|c|c|c|c|}
\hline \multirow[t]{2}{*}{ No } & \multirow[t]{2}{*}{ Pengulangan } & \multicolumn{2}{|c|}{ Kadar Fe (mg/L) } & \multirow[t]{2}{*}{ Penurunan (mg/L) } & \multirow{2}{*}{$\begin{array}{c}\text { Keefektifan } \\
(\%)\end{array}$} \\
\hline & & Sebelum & Sesudah & & \\
\hline 1 & P1 & & 0,84 & 1,73 & $67,32 \%$ \\
\hline 2 & P2 & 2,57 & 0,97 & 1,6 & $62,26 \%$ \\
\hline 3 & P3 & & 0,89 & 1,68 & $65,37 \%$ \\
\hline & Rata-rata & & 0,9 & 1,67 & 64,98 \\
\hline
\end{tabular}

Dari hasil pengukuran kadar besi yang mengalami penurunan pada sampel air sumur bor sebelum dilakukan perlakuan sebesar $2,57 \mathrm{mg} / \mathrm{L}$ dan sesudah dilakukan perlakuan dengan menggunakan saringan cangkang telur bebek menunjukan bahwa dari 3 kali pengulangan kadar besi pada air mengalami penurunan dari sebelum dilakukan perlakuan dengan sesudah dilakukan perlakuan. Penurunan kadar besi pada air sumur bor setelah dilakukan perlakuan berkisar antara 1,6 mg/L (62,26\%) sampai $1,73 \mathrm{mg} / \mathrm{L}(67,32 \%)$. Adapun hasil rata-rata penurunan kadar besi pada air setelah dilakukan perlakuan sekitar 1,67 $\mathrm{mg} / \mathrm{L}(64,98 \%)$.

Tabel 6. Hasil Pengukuran Kadar Besi Menggunakan Saringan $60 \mathrm{~cm}$

\begin{tabular}{|c|c|c|c|c|c|}
\hline \multirow[t]{2}{*}{ No } & \multirow[t]{2}{*}{ Pengulangan } & \multicolumn{2}{|c|}{ Kadar Fe (mg/L) } & \multirow[t]{2}{*}{ Penurunan (mg/L) } & \multirow{2}{*}{$\begin{array}{c}\text { Keefektifan } \\
(\%)\end{array}$} \\
\hline & & Sebelum & Sesudah & & \\
\hline 1 & P1 & & 1,06 & 1,51 & $58,75 \%$ \\
\hline 2 & P2 & 2,57 & 1,03 & 1,54 & $59,92 \%$ \\
\hline 3 & P3 & & 1,11 & 1,46 & $56,81 \%$ \\
\hline & Rata-ra & & 1,06 & 1,50 & $58,49 \%$ \\
\hline
\end{tabular}

Dari hasil pengukuran kadar besi yang mengalami penurunan maka pada sampel air sumur bor sebelum dilakukan perlakuan sebesar $2,57 \mathrm{mg} / \mathrm{L}$ dan sesudah dilakukan perlakuan dengan menggunakan saringan cangkang telur bebek menunjukan bahwa dari 3 kali pengulangan kadar besi pada air mengalami penurunan dari sebelum dilakukan perlakuan dengan sesudah dilakukan perlakuan. Pengukuran terhadap Penurunan kadar besi pada air sumur bor setelah dilakukan perlakuan berkisar antara $1,46 \mathrm{mg} / \mathrm{L}(56,81 \%)$ sampai 1,54 $\mathrm{mg} / \mathrm{L}(59,92 \%)$. Adapun hasil rata-rata penurunan kadar besi pada air setelah dilakukan perlakuan sekitar 1,50 mg/L (58,49\%). Penurunan kadar besi tersebut juga dapat dilihat pada grafik 1 berikut: 


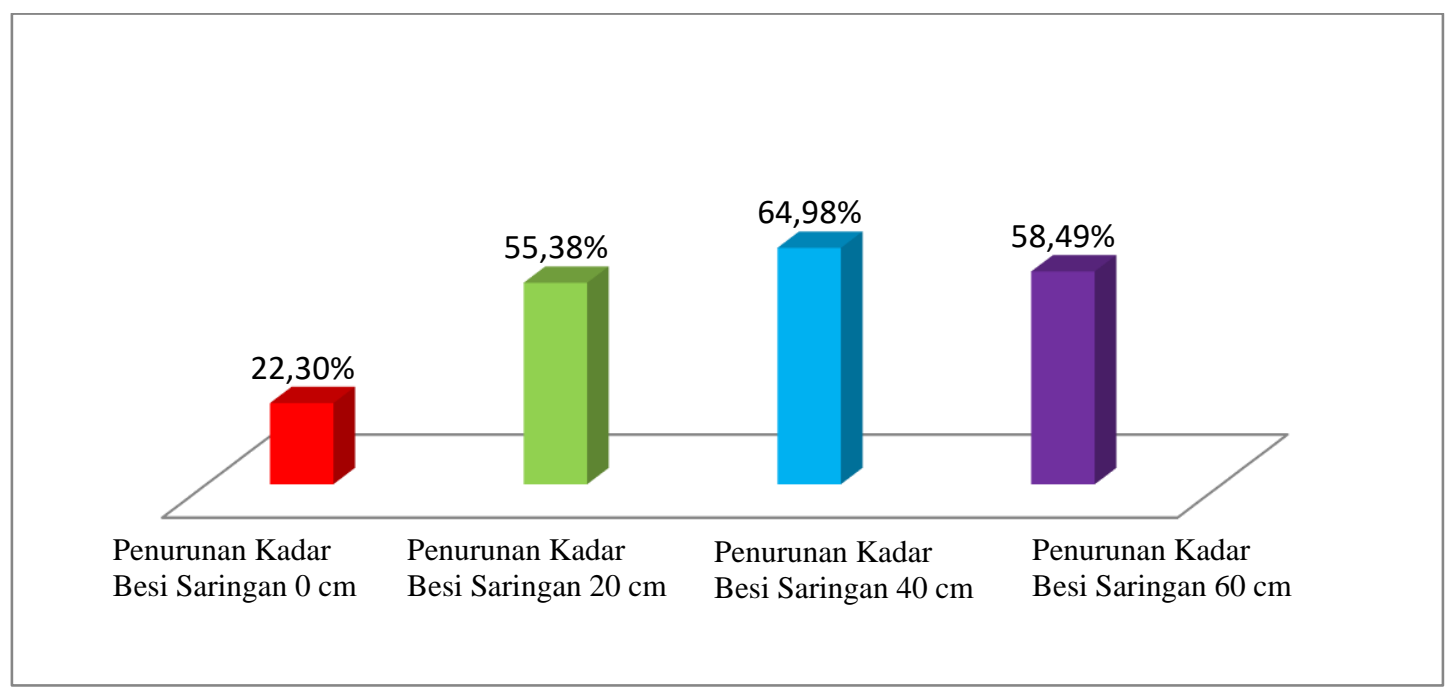

Gambar 1. Penurunan Kadar Besi

Berdasarkan hasil grafik diatas
rata-rata penurunan kadar besi menunjukkan bahwa pada saringan $0 \mathrm{~cm}$ yaitu sekitar 22,30\%, pada saringan 20 $\mathrm{cm}$ yaitu 55,38\%, sedangkan pada saringan $40 \mathrm{~cm}$ yaitu $64,98 \%$ dan pada saringan $60 \mathrm{~cm}$ yaitu $58,49 \%$. Hasil diatas menunjukkan bahwa yang paling efektif dalam menurunkan kadar besi yaitu pada saringan $40 \mathrm{~cm}$.

Tabel grafik diatas menunjukan terdapat kenaikan suhu dari suhu awal 26,6-27. Dikatakan bahwa yang mempengaruhi terhadap oksigen terlarut di dalam air yaitu adalah suhu yang tinggi, dengan kata lain bahwa semakin suhu air tinggi, maka akan mengakibatkan semakin berkurangnya kadar oksigen terlarut pada suhu tinggi terjadi oksidasi yang merubah carbon menjadi carbon dioxide.

Tabel 2 menunjukkan hasil jika dalam keadaan rendah $\mathrm{pH}$ air akan mempengaruhi kadar besi di dalam air sehingga terbentuk ferri dan ferro, serta menyebabkan warna dan adanya rasa karat pada air, $\mathrm{pH}$ air yang tidak mempengaruhi perubahan kandungan besi yaitu $\mathrm{pH}$ 6,5-8,5[2]. Peningkatan $\mathrm{pH}$ yang awalnya asam menjadi netral ini dipengaruhi oleh senyawa kalsium karbonat $\mathrm{CaCO} 3$ senyawa ini terdapat pada cangkang telur bebek. Cangkang telur bebek memiliki banyak pori-pori yang berukuran nano sehingga diperkirakan dapat digunakan sebagai adsorben yang lebih efektif. Cangkang telur bebek dapat menyerap Besi sekaligus untuk menetralisir kandungan asam yang ada pada air.

Tabel 3 menunjukkan hasil pengukuran pada kadar besi sampel air sumur bor di Pondok Pesantren Hidayatullah Banjarbaru dilakukan sebelum dan setelah dilakukan perlakuan menggunakan metode saringan cangkang telur bebek dengan variasi ketebalan yang berbeda yaitu $20 \mathrm{~cm}, 40 \mathrm{~cm}$ dan $60 \mathrm{~cm}$. Variasi ketebalan $20 \mathrm{~cm}$ setelah dilakukan perlakuan berkisar antara $1,14 \mathrm{mg} / \mathrm{L}$ (44,36\%) sampai $1,81 \mathrm{mg} / \mathrm{L} \quad(70,43 \%)$. Sedangkan untuk variasi ketebalan $40 \mathrm{~cm}$ setelah dilakukan perlakuan penurunan kadar besi berkisar antara 1,6 mg/L (62,26\%) sampai $1,73 \mathrm{mg} / \mathrm{L} \quad(67,32 \%)$. Dan untuk variasi ketebalan $60 \mathrm{~cm}$ setelah dilakukan perlakuan penurunan kadar besi berkisar antara 1,46 mg/L (56,81\%) sampai 1,54 mg/L (59,92\%). Hasil penurunan kadar besi yang paling efektif terdapat pada saringan $40 \mathrm{~cm}$.

Berdasarkan standar persyaratan tentang air bersih menurut Permenkes RI No. 32 tahun 2017 dimana standar untuk kadar besi yaitu 1,00 mg/L, sehingga pada proses filtrasi menggunakan saringan cangkang telur bebek dengan variasi ketebalan $20 \mathrm{~cm}, 40 \mathrm{~cm}$, dan $60 \mathrm{~cm}$ belum memenuhi standar baku mutu[2]. Pada semua proses perlakuan kadar besi terjadi penurunan meskipun hasilnya masih belum memenuhi standar 
persyaratan. Pada uji penelitian ini untuk mengoptimalkan hasilnya harus ada cara lain yaitu dengan menggunakan koagulan, saringan pasir dan pengendapan agar kualitas air yang telah diolah dapat memenuhi standar yang ditetapkan serta pengaturan laju debit air yang konsisten.

Hasil Uji Normalitas dapat diketahui bahwa data distribusi sampel air sudah normal untuk kadar besi(Fe). Nilai Sig > $\propto(0,05)$. Karena semua data berdistribusi normal maka dilanjutkan dengan uji One Way Anova. Hasil dari Uji Anova di dapatkan asymp < $00.000<$ 0.05) artinya ada perbedaan antara ketebalan saringan cangkang telur bebek $0 \mathrm{~cm}, 20 \mathrm{~cm}, 40 \mathrm{~cm}, 60 \mathrm{~cm}$ terhadap penurunan kadar besi. Maka dilakukan Uji lanjutan (LSD). Hasil Uji Posh Hoc Tests dapat disimpulkan bahwa ada perbedaan yang bermakna antara ketebalan saringan cangkang telur bebek $20 \mathrm{~cm}, 40 \mathrm{~cm}, 60 \mathrm{~cm}$ karena nilai Signifikan pada output Multiple Comparisons Test $<0,05$. Sedangkan untuk Hasil Uji Normalitas dapat diketahui bahwa data sampel air tidak berdistribusi normal. Maka dilanjutkan uji Kruskal-Wallis. Hasil dari Uji Kruskal-Wallis di dapatkan asymp $<\propto$ $(0.016<0.05)$ artinya ada perbedaan nilai $\mathrm{pH}$ antara ketebalan saringan cangkang telur bebek $0 \mathrm{~cm}, 20 \mathrm{~cm}, 40 \mathrm{~cm}, 60 \mathrm{~cm}$ terhadap perubahan nilai $\mathrm{pH}$ pada sampel air sumur bor. Maka uji lanjutan Mann Whitney. Hasil Uji Mann-Whitney dikatakan bahwa nilai asymp. Sig. (2tailed) $0,043<0,05$. Disimpulkan bahwa ada perbedaan nilai $\mathrm{pH}$ antara ketebalan saringan cangkang telur bebek $0 \mathrm{~cm}, 20$ $\mathrm{cm}, 40 \mathrm{~cm}, 60 \mathrm{~cm}$. Karena ada perbedaan yang signifikan maka dapat dikatakan bahwa ada pengaruh ketebalan saringan cangkang telur bebek terhadap hasil nilai $\mathrm{pH}$ pada air sumur bor.

\section{KESIMPULAN DAN SARAN}

Hasil pengukuran kadar besi yang mengalami penurunan sebelum dilakukan perlakuan yaitu 2,57 $\mathrm{mg} / \mathrm{L}$ dan setelah dilakukan perlakuan pada variasi ketebalan saringan $20 \mathrm{~cm}$ berkisar antara $1,14 \mathrm{mg} / \mathrm{L}(44,36 \%)$ sampai $1,81 \mathrm{mg} / \mathrm{L}$ (70,43\%), variasi ketebalan $40 \mathrm{~cm}$ berkisar antara $1,6 \mathrm{mg} / \mathrm{L} \quad(62,26 \%)$ sampai $1,73 \mathrm{mg} / \mathrm{L}(67,32 \%)$, dan variasi ketebalan $60 \mathrm{~cm}$ berkisar antara 1,46 $\mathrm{mg} / \mathrm{L} \quad(56,81 \%)$ sampai $1,54 \mathrm{mg} / \mathrm{L}$ (59,92\%). Penurunan kadar besi (Fe) pada variasi ketebalan yang paling efektif yaitu pada variasi saringan $40 \mathrm{~cm}$ dengan berat 291 gram.

Perlu adanya penambahan bahan koagulan dan penggunaan media yang lain agar memenuhi standar persyaratan kualitas air bersih.

\section{KEPUSTAKAAN}

1. D. S. Atika, A. Fitriani, and D. Pramita. (2014). Pemanfaatan Limbah Cangkang Telur Ayam Sebagai Pengadsorbsi Logam Merkuri Di Sungai Kapuas Kalimantan Barat.

2. Peraturan Menteri Kesehatan Republik Indonesia Nomor 32 Tahun 2017. Tentang Persyaratan Kesehatan Air Untuk Keperluan Higiene Sanitasi.

3. Pradopo, R.J. (2020). Efektivitas Saringan Cangkang Telur Bebek Dalam Memperbaiki Kualitas pH dan Besi Air Sumur Bor. Skripsi. Prodi Sanitasi Lingkungan Program Sarjana Terapan. Poltekkes Kemenkes Banjarmasin. 